\title{
An Analysis of the Impact of Indo-Lanka Free Trade Agreement and Its Implications for Free Trade in South Asia
}

\author{
Mahinda Siriwardana \\ University of New England
}

\begin{abstract}
The Indo-Lanka Free Trade Agreement (ILFTA) which was signed in December 1998 between India and Sri Lanka has shown a promising start to trade liberalisation among SAARC (South Asian Association for Regional Cooperation) countries. This paper provides a quantitative assessment of the likely impact of the ILFTA. We perform simulations using the Global Trade Analysis Project (GTAP) model to quantify the impact of liberlised trade between Sri Lanka and India. GTAP is a computable general equilibrium (CGE) model of the world economy. Using the model simulations, the paper also examines the implications of extending the free trade agreement to other SAARC nations. Results indicate that both Sri Lanka and India will experience some welfare gains from ILFTA. The extension of such trade agreement to all SAARC nations may create significant welfare improvements in Sri Lanka.
\end{abstract}

- JEL Classification: F15

- Key words: Free Trade Agreement, General Equililorium, GTAP

\section{Introduction}

After several years of planning and contentious discussions, the governments of Sri Lanka and India signed a bilateral free trade agreement in December 1998 (CBS, 1999). Since then it took further period of negotiations to decide exact terms

*Corresponding address: Mahinda Siriwardana, School of Economics University of New England, Armidale, N.S.W., Australia 2351, Phone: 02-67 732501; Email: asiriwar@metz.une.edu.au (C)2004-Center for International Economics, Sejong Institution, All Rights Reserved. 
and conditions of this historic Indo-Lanka Free Trade Agreement (ILFTA) prior to its implementation in March 2000. This trade agreement is regarded as a significant landmark in establishing a free trade area in South Asia under the auspicious of the South Asia Free Trade Agreement (SAFTA) which has now reached the final stage of negotiations. The SAFTA is organised under the umbrella of the South Asian Association for Regional Corporation (SAARC). ${ }^{1}$ While the ultimate configuration of the free trade agreement for the region will be driven by a variety of political and economic considerations and negotiated outcomes, it is useful to provide some quantitative assessment of the ILFTA facilitating the debate of free trade in South Asia. This paper offers some preliminary findings of the impact of the ILFTA on both economies of Sri Lanka and India and attempts to evaluate the effects of expanding this agreement to include the other SAARC nations.

We use the multi-country computable general equilibrium (CGE) model developed at the Global Trade Analysis Project (GTAP) to examine the impact of trade liberalisation as proposed in the ILFTA. The GTAP model (Hertel, 1996) covers the world economy and has been widely used in studies dealing with trade policy analysis at global level. The simulations from the model help in understanding the impact on trade, production, and resource allocation that might occur in different economies and sectors due to the adoption of changes in different tariff structures.

The paper is organised as follows. Section II examines the economic structure and the trade patterns in the South Asian region and compares it with the world economy. A brief review of some important features of the ILFTA is provided in Section III. An overview of the GTAP model is presented in Section IV. Section V outlines three different trade liberalisation scenarios that have been evaluated using the GTAP model. Simulation results are reported and discussed in Section VI. Section VII concludes.

\section{Patterns of Trade and Economic Structure}

We have aggregated 45 regions in the GTAP model into ten regions for the purpose of analysis in this paper. ${ }^{2}$ Table 1 presents some economic indicators of the countries and regions in terms of external trade, GDP, factor endowments and

\footnotetext{
'The SAARC was formed in 1985 with representative countries of Bangladesh, Buthan, India, Maldives, Nepal, Pakistan, and Sri Lanka (Mukherji, 1998).

${ }^{2}$ See Appendix Table A1 for details.
} 
Table 1. Factor endowments, Income Shares, Factor Intensity, and Trade Dependence (1995)

\begin{tabular}{lcccccccccc}
\hline & NAM & JPN & ANZ & CHN & REA & IND & LKA & RSA & EU & ROW \\
\hline $\begin{array}{l}\text { GDP \& Trade Flows } \\
\text { (billion U.S.\$): }\end{array}$ & & & & & & & & & & \\
& & & & & & & & & & \\
Exports & 1043.5 & 502.1 & 82.9 & 289.7 & 598.5 & 39.4 & 4.4 & 14.8 & 2336.0 & 922.3 \\
$(\%)$ & 17.9 & 8.6 & 1.4 & 5.0 & 10.3 & 0.7 & 0.1 & 0.3 & 40.0 & 15.7 \\
& & & & & & & & & & \\
Imports & 1133.9 & 435.3 & 87.9 & 279.6 & 649.4 & 40.3 & 5.5 & 21.6 & 2296.8 & 940.3 \\
$(\%)$ & 19.3 & 7.4 & 1.5 & 4.7 & 11.0 & 0.7 & 0.1 & 0.4 & 39.0 & 15.9 \\
& & & & & & & & & & \\
GDP & 7980.0 & 5091.7 & 405.3 & 813.4 & 1340.9 & 329.3 & 13.2 & 91.5 & 8209.7 & 4039.3 \\
$(\%)$ & 28.2 & 18.0 & 1.4 & 2.9 & 4.7 & 1.2 & 0.0 & 0.3 & 29.0 & 14.3
\end{tabular}

Trade Dependence (\%):

$\begin{array}{lcccccccccc}\text { Exports/GDP } & 13.1 & 9.9 & 20.5 & 35.6 & 44.6 & 11.9 & 33.3 & 16.2 & 28.5 & 22.8 \\ \text { Imports/GDP } & 14.2 & 8.5 & 21.7 & 34.4 & 48.4 & 12.2 & 41.7 & 23.6 & 28.0 & 23.3 \\ & & & & & & & & & & \\ \begin{array}{l}\text { Factor Shares in Regional } \\ \text { Value Added(\%): }\end{array} & & & & & & & & & & \\ & & & & & & & & & & \\ \text { Land } & 0.5 & 0.5 & 0.8 & 5.0 & 4.5 & 12.4 & 10.8 & 13.1 & 0.3 & 2.1 \\ \text { Labour } & 62.5 & 57.9 & 59.0 & 43.6 & 46.4 & 49.8 & 49.0 & 49.5 & 66.7 & 50.4 \\ \text { Capital } & 36.3 & 41.3 & 38.8 & 48.6 & 47.8 & 36.4 & 39.0 & 35.9 & 32.6 & 44.8 \\ \text { Resources } & 0.7 & 0.3 & 1.4 & 2.8 & 1.3 & 1.4 & 1.2 & 1.5 & 0.4 & 2.7\end{array}$

Factor Proportion (\%):

\begin{tabular}{lllllllllll} 
Unskilled/Total Labour & 60.6 & 62.5 & 59.4 & 78.0 & 70.6 & 81.3 & 77.7 & 80.7 & 61.6 & 69.8 \\
\hline
\end{tabular}

Source: GTAP Version 4 Database (McDougall et al., 1998).

factor proportions. The data are remarkably asymmetric among regions in their shares of the world's GDP, imports and exports. Within South Asia, the economic prominence of India is evident: It accounts for about 76 per cent of the GDP, 67 per cent of imports, and 60 per cent of exports of the region. Sri Lanka is relatively a minor player in South Asia. However, South Asia is small compared to other main trading partners as its share in world GDP is only 1.4 per cent and exports and imports also represent relatively small shares (1.2 and 1.1 per cents, respectively) in the world trade. Judging by these figures, any change in trade policy in South Asia is likely to have a negligible impact on the world economy.

Of the three South Asian regions of Table 1, Sri Lanka has the highest trade dependency ratio and it is indeed one of the most open economies in the world. Interestingly, it is only second to Rest of East Asia (REA) and is well above most 
Table 2. Export and Import Shares in World Trade by Sector in 1995 (\%)

\begin{tabular}{lcccccccccccc}
\hline & NAM & JPN & ANZ & CHN & REA & IND & LKA & RSA & EU & ROW Total \\
\hline Shares in world exports: & & & & & & & & & & & \\
& & & & & & & & & & & \\
Agricultural products & 5.1 & 0.3 & 3.8 & 2.5 & 9.7 & 3.1 & 0.1 & 0.8 & 46.2 & 28.4 & 100.0 \\
Processed foods & 12.6 & 0.6 & 4.2 & 2.6 & 10.5 & 1.0 & 0.2 & 0.3 & 45.6 & 22.4 & 100.0 \\
Mining & 10.6 & 0.7 & 3.6 & 1.4 & 7.6 & 1.7 & 0.1 & 0.0 & 16.4 & 57.9 & 100.0 \\
Textiles \& apparel & 6.2 & 2.3 & 1.3 & 20.1 & 16.8 & 2.6 & 0.5 & 2.4 & 32.8 & 15.0 & 100.0 \\
Other manufacturing & 19.0 & 12.3 & 0.7 & 3.8 & 11.4 & 0.3 & 0.0 & 0.0 & 42.9 & 9.6 & 100.0 \\
Services & 19.6 & 5.6 & 1.7 & 6.0 & 8.9 & 0.5 & 0.1 & 0.2 & 41.7 & 15.7 & 100.0 \\
& & & & & & & & & & & \\
Total exports & 17.4 & 8.6 & 1.4 & 5.0 & 11.0 & 0.7 & 0.1 & 0.3 & 40.0 & 15.5 & 100.0 \\
& & & & & & & & & & & \\
Shares in world imports: & & & & & & & & & & & \\
& & & & & & & & & & & \\
Agricultural products & 35.4 & 0.1 & 2.6 & 2.0 & 4.4 & 2.3 & 0.1 & 0.6 & 31.3 & 21.2 & 100.0 \\
Processed foods & 13.0 & 0.6 & 4.3 & 2.8 & 11.1 & 1.1 & 0.2 & 0.3 & 43.8 & 22.8 & 100.0 \\
Mining & 10.9 & 0.7 & 3.8 & 1.6 & 7.7 & 1.6 & 0.1 & 0.0 & 16.1 & 57.5 & 100.0 \\
Textiles \& apparel & 6.2 & 2.3 & 1.3 & 19.8 & 17.1 & 2.8 & 0.5 & 2.4 & 32.7 & 14.9 & 100.0 \\
Other manufacturing & 19.0 & 12.2 & 0.7 & 3.8 & 11.6 & 0.3 & 0.0 & 0.0 & 42.8 & 9.6 & 100.0 \\
Services & 20.5 & 5.5 & 1.7 & 5.9 & 8.8 & 0.5 & 0.1 & 0.2 & 41.2 & 15.6 & 100.0 \\
& & & & & & & & & & & \\
Total imports & 17.6 & 8.5 & 1.4 & 5.0 & 11.1 & 0.7 & 0.1 & 0.3 & 39.7 & 15.6 & 100.0 \\
\hline Soure: GTAP Vers
\end{tabular}

Source: GTAP Version 4 Database (McDougall et al., 1998).

developed economies in its dependence on international trade. Table 1 also suggests a significant variation in factor endowments between the South Asian economies and other economies in the world, suggesting that there is an ample scope for Heckscher-Ohlin type trade to occur. It is noticeable that the three regions in South Asia have similar factor shares which may influence more intraindustry trade than inter-industry trade among themselves. They also have higher shares of unskilled labour in the labour force in comparison to other economies.

Table 2 reports the share of each regions exports and imports by sector in total world trade. South Asian countries represent relatively small shares which are consistent with their small GDP levels. It appears that agricultural products, and textiles and apparel are the leading exports from and imports into the region. Of the worlds total exports and imports, South Asia accounts for about 1.1 per cent of which Indias share is more than 50 per cent, showing its dominant position in the region.

Trade between Sri Lanka and its South Asian trading partners are reported in Table 3. India is the main source of imports to Sri Lanka from the region as well as the principal destination of its exports to South Asia. Over the ten-year period between 1990 and 1999, trade between India and Sri Lanka has grown 
Table 3. Sri Lanka's Trade with South Asia (US\$ millions)

\begin{tabular}{|c|c|c|c|c|c|c|c|c|c|c|c|c|}
\hline \multirow{2}{*}{ Country } & \multicolumn{6}{|c|}{ Sri Lanka's Exports to } & \multicolumn{6}{|c|}{ Sri Lanka's Imports from } \\
\hline & 1990 & $\%$ & 1995 & $\%$ & 1999 & $\%$ & 1990 & $\%$ & 1995 & $\%$ & 1999 & $\%$ \\
\hline$\overline{\text { Bangladesh }}$ & 10.0 & 14.5 & 12.0 & 11.9 & 6.7 & 5.7 & 9.0 & 4.9 & 6.0 & 1.1 & 4.9 & 0.6 \\
\hline India & 20.0 & 29.0 & 32.0 & 31.7 & 48.5 & 41.3 & 118.0 & 64.1 & 469.0 & 86.1 & 666.3 & 83.4 \\
\hline Maldives & 7.0 & 10.1 & 14.0 & 13.9 & 30.1 & 25.6 & 6.0 & 3.3 & 17.0 & 3.1 & 18.1 & 2.3 \\
\hline Nepal & 0.0 & 0.0 & 0.0 & 0.0 & 0.0 & 0.0 & 0.0 & 0.0 & 1.0 & 0.2 & 0.0 & 0.0 \\
\hline Pakistan & 32.0 & 46.4 & 43.0 & 42.5 & 32.1 & 27.4 & 51.0 & 27.7 & 52.0 & 9.5 & 109.7 & 13.7 \\
\hline Total & 69.0 & 100.0 & 101.0 & 100.0 & 117.4 & 100.0 & 184 & 100.0 & 545.0 & 100.0 & 799.0 & 100.0 \\
\hline World & 1983.0 & & 3798.0 & & 4599.3 & & 2685 & & 5185 & & 5893.0 & \\
\hline As $\%$ & 3.5 & & 2.7 & & 2.6 & & 10.6 & & 10.5 & & 13.6 & \\
\hline
\end{tabular}

Source: IMF, Direction of Trade Statistics Yearbook (various issues)

Figure 1. Sri Lanka's Trade with India

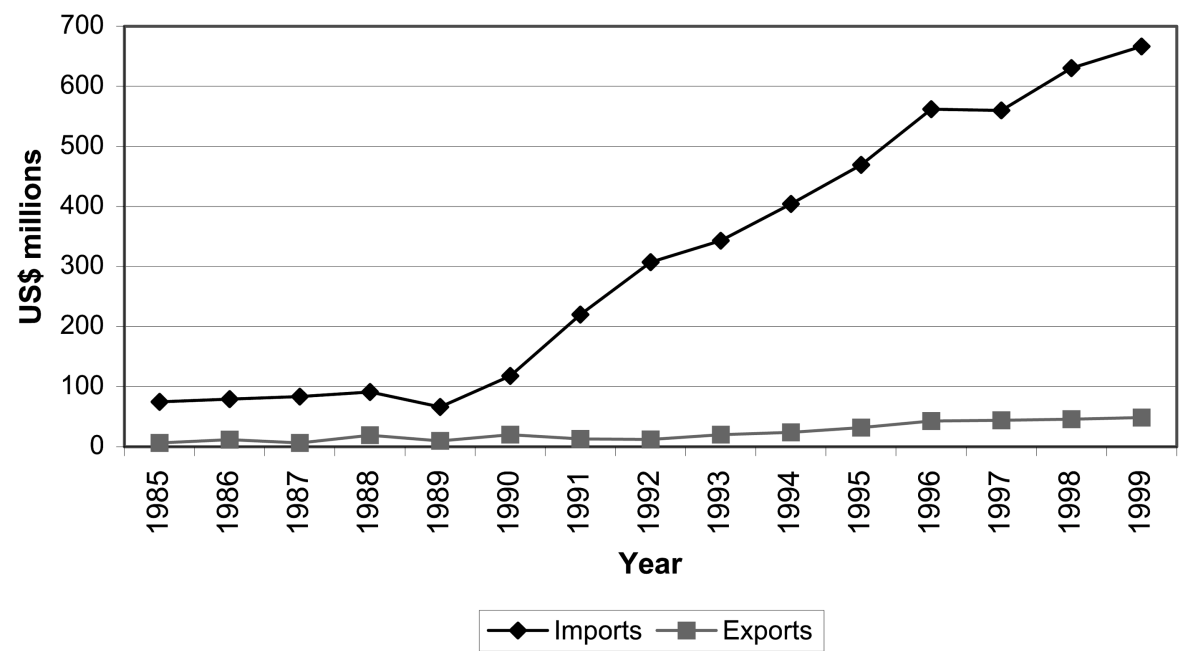

Source: IMF, Direction of Trade Statistics Yearbook (various issues)

remarkably. As can be seen from Figure 1, Sri Lanka's trade deficit against India has widened at an alarming rate over the same period. Though Pakistan appears to be the second important trading partner for Sri Lanka in the region, its relative importance is on a declining trend. While the trade between Sri Lanka and Bangladesh has also declined over recent years, exports to Maldives show a healthy growth in 1999. As can be seen from Table 3, Sri Lankas exports to South Asia are generally low (about 3 per cent of its total exports) whereas imports account for a reasonable proportion (about 14 per cent of the total).

Calculated from the GTAP database (version 4), Table 4 shows the bilateral ad valorem tariff rates applicable to different sectors by source of imports in the 
Table 4. Sectoral Bilateral Import Tariffs (percent ad valorem)

\begin{tabular}{|c|c|c|c|c|c|c|}
\hline \multirow{3}{*}{ Sector } & \multicolumn{2}{|c|}{ SRI LANKA } & \multicolumn{2}{|c|}{ INDIA } & \multicolumn{2}{|c|}{$\begin{array}{c}\text { REST OF } \\
\text { SOUTH ASIA }\end{array}$} \\
\hline & On & On Rest of & On Sri & On Rest of & On Sri & On \\
\hline & India & South Asia & Lanka & South Asia & Lanka & India \\
\hline 1. Rice & 12.0 & 12.0 & 4.0 & 4.0 & 13.0 & 13.0 \\
\hline 2. Wheat & -16.0 & -16.0 & -16.0 & -16.0 & -16.0 & -16.0 \\
\hline 3. Other cereal grains & -2.0 & -2.0 & -2.0 & -2.0 & -2.0 & -2.0 \\
\hline 4. Vegetables \& fruits & 35.0 & 32.0 & 51.0 & 63.0 & 83.0 & 80.0 \\
\hline 5. Sugar & 24.0 & 0.0 & 68.0 & 59.0 & 100.0 & 57.0 \\
\hline 6. Plant-based fibers & 0.0 & 10.0 & 50.0 & 40.0 & 60.0 & 61.0 \\
\hline 7. Other crops & 33.0 & 13.0 & 55.0 & 39.0 & 100.0 & 29.0 \\
\hline 8. Meat products & 11.0 & 6.0 & 58.0 & 27.0 & 24.0 & 7.0 \\
\hline 9. Vegetable oil \& fats & 11.0 & 35.0 & 65.0 & 64.0 & 61.0 & 50.0 \\
\hline 10. Milk products & 0.0 & 0.0 & 0.0 & 28.0 & 13.0 & 17.0 \\
\hline 11. Other food products & 17.0 & 11.0 & 61.0 & 58.0 & 86.0 & 49.0 \\
\hline 12. Beverages \& tobacco & 164.0 & 164.0 & 250.0 & 351.0 & 215.0 & 214.0 \\
\hline 13. Mining & 20.0 & 14.0 & 50.0 & 54.0 & 60.0 & 60.0 \\
\hline 14. Textiles & 21.0 & 20.0 & 58.0 & 58.0 & 100.0 & 71.0 \\
\hline 15. Weaving apparel \& leather & 31.0 & 28.0 & 61.0 & 60.0 & 100.0 & 99.0 \\
\hline 16. Wood \& wood products & 14.0 & 10.0 & 11.0 & 34.0 & 96 & 99.0 \\
\hline 17. Paper \& paper products & 20.0 & 20.0 & 64.0 & 36.0 & 86.0 & 53.0 \\
\hline 18. Chemical, rubber \& plastic & 11.0 & 1.0 & 52.0 & 61.0 & 91.0 & 86.0 \\
\hline 19. Nonmetallic mineral products & 12.0 & 34.0 & 51.0 & 50.0 & 95.0 & 64.0 \\
\hline 20. Basic metal products & 13.0 & 15.0 & 7.0 & 52.0 & 100.0 & 82.0 \\
\hline 21. Fabricated metal products & 20.0 & 16.0 & 53.0 & 53.0 & 81.0 & 83.0 \\
\hline 22. Other manufactures & 23.0 & 13.0 & 64.0 & 65.0 & 100.0 & 93.0 \\
\hline 23. Construction & 0.0 & 0.0 & 0.0 & 0.0 & 0.0 & 0.0 \\
\hline 24. Services & 0.0 & 0.0 & 0.0 & 0.0 & 0.0 & 0.0 \\
\hline
\end{tabular}

Source: GTAP Version 4 Database (McDougall et al., 1998).

Note: Negative values imply import subsidies.

South Asian region. While there is a significant variation in tariff rates between sectors, the rates reported in the table clearly indicate that Sri Lanka is by far the most liberalised economy among the South Asian countries. Except for the beverages and tobacco sector, the ad valorem rate of tariffs for other sectors ranges from zero to 35 per cent in Sri Lanka. The tariff barriers are uniformly high across sectors in India and even higher in RSA.

\section{Indo-Lanka Free Trade Agreement}

There is a considerable debate over the benefits of regional trading arrangements (RTA) as opposed to multilateral free trade (Krueger, 1999). RTAs could both 
create and divert trade or perhaps only trade diverting. It has been argued that as developing economies usually maintain high tariff barriers they may lose from RTAs due to trade diversion as they rely heavily on RTA partners (Bhagwati and Panagariya, 1996; Panagariya, 1996, 1998, 1999). On the one hand, small developing countries such as Sri Lanka may lose considerable tariff revenue with trade liberalisation and on the other hand their price taking behaviour in the world markets results in higher prices being faced by domestic consumers despite tariff cuts ${ }^{3}$.

There has be a considerable opposition to the ILFTA by domestic industrialists in both Sri Lanka and India. Both economies have an important import-competing sector which is likely to be hurt as two countries move toward free trade. As seen from data in Table 3, 83 per cent of imports to Sri Lanka from the region are from India and it accounts for 49 per cent of Sri Lankan exports to the region. The free flow of Indian products to the domestic market in Sri Lanka and the exploitation of the Indian market by Sri Lankan exporters may become the natural outcome when the free trade agreement becomes fully operational. As the smaller partner of RTA, the extent of the likely welfare implications for Sri Lanka could be enormous.

Table 5 briefly outlines the salient features of the ILFTA. While most of the details in the table are self-explanatory, perhaps some explanation is in order with respect to the "negative list". The negative list was drawn by both countries to safeguard the domestic consumer-goods sector which may find foreign competition a severe threat to its long-term survival. In the case of Sri Lanka, the "negative list" contains manufactured industry products which are still at their infancy and most of the agricultural products. Likewise, the Indian "negative list includes goods such as garments, alcohol, coconut and coconut oil which Sri Lanka can produce competitively (Siriwardana, 2001).

\section{Overview of the GTAP Model}

The analytical framework used to quantify the impact of bilateral tariff reductions is the well-known GTAP model (Hertel, 1996). It is a comparativestatic multi-regional CGE model of the Johansen type comprising a system of linear equations in percentage change of variables. The modelling of each region in GTAP is based on the ORANI model (Dixon et al., 1982). We use the latest version of GTAP together with version four of the database which distinguishes 45

${ }^{3}$ See also Sirinivasan $(1994,1998)$. 
Table 5. The Salient Features of the Indo-Lanka Free Trade Agreement

\section{Reduction of Tariffs:}

By India

(i) 100 per cent removal of tariffs on 1351 items upon entry into force of the agreement (Annexure E).

(ii) 25 per cent tariff reduction for 528 textile items (all textile items in Chapters 51, 52, 58, 59, 60, 63 and a majority of textile items in Chapters 53-56).

(iii) Except 429 items in the negative list of India (Annexure D (i) ), 50 per cent reduction of tariffs for the remaining 2797 items upon entry into force of the agreement followed by phased out removal of tariffs up to 100 per cent in 2 stages within three years.

(iv) A 50 per cent fixed tariff concession for imports of tea from Sri Lanka on a preferential basis subject to an annual maximum quota of up to 15 million $\mathrm{kgs}$.

(v) A 50 per cent fixed tariff concession for imports of garments from Sri Lanka subject to a maximum annual quota of 8 million pieces of which a minimum of 6 million pieces should contain Indian fabrics.

\section{By Sri Lanka}

(i) 100 per cent removal of tariffs on 319 items (raw materials and machinery for industries) upon entry into force of the agreement (Annexure F 1).

(ii) 50 per cent reduction of tariffs on 889 items upon entry into force of the agreement (Annexure F II) followed by phased out removal of tariffs as follows:

up to 70 per cent at the end of the first year up to 90 per cent at the end of the second year up to 100 per cent at the end of the third year

(iii) For 1180 items in Sri Lanka's negative list (Annexure D (ii)), there will be no duty preferences.

(iv) For the remaining 2724 items, upon entry into force of the agreement, the removal of tariffs will be phased out within eight years as follows:

not less than 35 per cent before the end of the third year not less than 70 per cent before the end of the sixth year not less than 100 per cent before the end of the eighth year

Source: This information on free trade agreement was obtained from http://www.tradenetsl.sl/INDIA/fta/ conind.htm and http://www.tradenetsl.sl/INDIA/fta/consl.htm

regions and 50 sectors in each region.

The model has many general features which include product differentiation by country of origin, explicit recognition of savings by regional economies, a capital goods producing sector in each region to service investment, international mobility of capital, multiple trading regions, multiple goods and primary factors, empirically based differences in production technology and consumer preferences across regions, and explicit recognition of a global transport sector. It is also featured by many policy variables, including taxes and subsidies on commodities as well as on primary factors, making the model more attractive to policy analysts.

In each region both factor and commodity markets are assumed to be perfectly 
Figure 2. Production Structure in GTAP

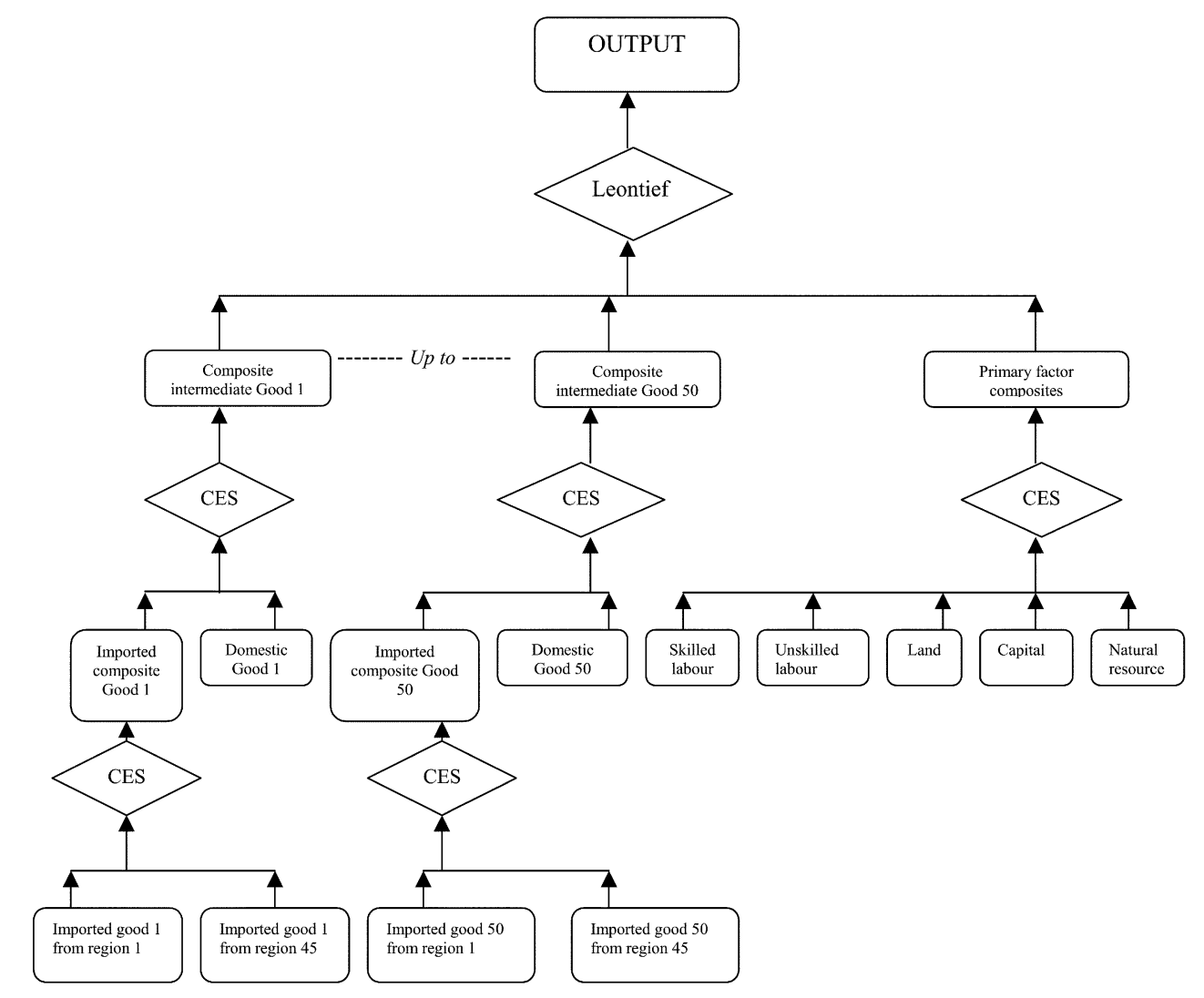

competitive. Figure 2 displays the assumed technology for firms in each of the industries in every region of the model. The production technology is described by a three stage nested Leontief and CES (constant elasticities of substitution) production functions. Two broad categories of inputs to production are identified, namely intermediate inputs and primary factors. Each regional sector is assumed to choose a mixture of inputs to minimise total cost for a given level of output. At the first level, producers use composite units of intermediate inputs and primary factors in fixed proportions according to a Leontief function. As can be seen from Figure 2, 50 different composite intermediate inputs are available to each producer. At the second level of the production nest, intermediate input composites are obtained as combinations of imported composites and domestic goods of the same inputoutput class, and primary factor input composites are created as combinations of skilled-labour, unskilled-labour, land, capital and natural resources. A CES function is used in forming both types of composites. Finally at the third level, 
imported composites are created via a CES aggregation of imported goods of the same class from each region.

The firm's decision to combine different inputs to produce its output largely depends on the separability assumption adopted in production. For instance, it is assumed that producers choose their optimal mix of primary factors independently of the prices of intermediate inputs. By allowing the separability of this type, we impose the restriction that the elasticity of substitution between any individual primary factors is equal via the CES function. Adopting the CES function in the selection of intermediate inputs imposes a similar restriction. Imported intermediates are separable from domestically produced intermediate inputs. As shown in Figure 2, producers first decide on the source of their imports and generate imported composites via CES function. Then depending on the imported composite price and the domestic good's price, they then determine the optimal mix of imported composite and domestic good of the same input-output class. This is the well known "Armington approach" to modelling import demand.

Under the assumption of perfectly competitive factor markets, payments to primary factors skilled labour, unskilled labour, capital, land, and natural resources are determined by the marginal productivity of these factors. Hence factor returns equal their marginal revenue product. For example, the wage rate for unskilled workers is equal to the marginal revenue product of unskilled labour. Under the assumption of full employment, GTAP can project the change in the nominal wage rate for unskilled labour. In a particular simulation, the change in the real wage for unskilled labour could be easily obtained by taking into account the change in the consumer price index.

On the demand side, the GTAP model adopts a sophisticated specification of consumer behaviour which allows for differences in both price and income responsiveness of demand in different regions, depending on the level of development and regional specific demand patterns. Each region has a single representative household. This regional household receives all the income generated through payments to primary factors, and net tax revenue. Its behaviour is governed by an aggregate utility function over private household consumption, government consumption, and savings. The aggregate utility is modelled by a Cobb-Douglas function with constant expenditure shares. The government consumption is also described by a Cobb-Douglas function over composite commodities where the demand for the latter is a CES aggregation of imports and domestic goods. Private household consumption is explained by a CDE (Constant Difference of 
Elasticities) expenditure function. These households purchase bundles of commodities where the bundles are CES aggregation of domestic goods and imported bundles. The imported bundles in turn are formed by a CES aggregation of imports from different regions.

Capital creation takes place in each region according to a technology that is similar to producing current goods except that it requires only domestic and imported intermediate inputs. This capital creation services the investment which is financed by a global pool of savings. Each region contributes a share of its income to a savings pool at a global bank. This bank is designed to mediate world savings and investment. There are two methods available in the standard GTAP model for allocating global savings to investment in each region. The first method allocates global savings across investment in a fixed proportion of the total savings so that the regional composition of global investment remains unaltered. The second method allows investment to take place in each region according to the relative rates of return.

As noted before, the version four of GTAP database divides the world into 45 countries and distinguishes 50 sectors (commodities). Given the focus of our study, we aggregate the database into 10 regions and 24 sectors as shown in the Appendix Table A1. As our focus is on the bilateral tariff reductions between Sri Lanka, India, and Rest of South Asia (RSA), the regional aggregation adopted highlights the importance of those trading partners within South Asia.

\section{Design of Alternative Scenarios of Trade Liberalisation with GTAP}

The simulation experiments conducted with the standard version of the GTAP model are outlined in this section. We present three trade liberalisation scenarios: Indo-Lanka partial free trade, Indo-Lanka-Rest of South Asia partial free trade, and Indo-Lanka-Rest of South Asia full free trade. Table 6 shows the respective percentage reductions in the sectoral ad valorem bilateral tariff rates by trading partners in our simulations. While our selection of the required percentage cut in tariff rates is somewhat crude given the complexity of the ILFTA, we have attempted to incorporate many of the features of the agreement including the "negative list".

The GTAP simulation for the scenario one (Indo-Lanka partial free trade) involved reducing bilateral ad valorem tariff rates by the percentages shown in 
Table 6. Levels of Bilateral Tariff Cuts Under Different Scenarios

\begin{tabular}{|c|c|c|c|c|c|c|c|c|c|c|}
\hline \multirow{3}{*}{ Sector } & \multicolumn{3}{|c|}{$\begin{array}{l}\text { Indo-Lanka Partial } \\
\text { Free Trade Scenario }\end{array}$} & \multicolumn{7}{|c|}{$\begin{array}{c}\text { Indo-Lanka-Rest of South Indo-Lanka-Rest of } \\
\text { Asia Partial Free Trade Sce-South Asia Full Free } \\
\text { nario } \\
\text { Trade Scenario }\end{array}$} \\
\hline & \multirow[b]{2}{*}{ LKA } & \multirow[b]{2}{*}{ IND } & \multirow[b]{2}{*}{ RAS } & \multirow[b]{2}{*}{ LKA } & \multirow[b]{2}{*}{ IND } & \multicolumn{2}{|c|}{ RSA } & \multirow[b]{2}{*}{ LKA } & \multirow[b]{2}{*}{ IND } & \multirow[b]{2}{*}{ RSA } \\
\hline & & & & & & $\begin{array}{c}\text { On } \\
\text { LKA }\end{array}$ & $\begin{array}{c}\text { On } \\
\text { IND }\end{array}$ & & & \\
\hline 1. Rice & 0 & 0 & 0 & 0 & 0 & 0 & 0 & 100 & 100 & 100 \\
\hline 2. Wheat & 0 & 0 & 0 & 0 & 0 & 0 & 0 & 100 & 100 & 100 \\
\hline 3. Other cereal grains & 0 & 0 & 0 & 0 & 0 & 0 & 0 & 100 & 100 & 100 \\
\hline 4. Vegetables \& fruits & 0 & 0 & 0 & 0 & 0 & 0 & 0 & 100 & 100 & 100 \\
\hline 5. Sugar & 0 & 0 & 0 & 0 & 0 & 0 & 0 & 100 & 100 & 100 \\
\hline 6. Plant-based fibers & 0 & 0 & 0 & 0 & 0 & 0 & 0 & 100 & 100 & 100 \\
\hline 7. Other crops & 0 & 0 & 0 & 0 & 0 & 0 & 0 & 100 & 100 & 100 \\
\hline 8. Meat products & 0 & 0 & 0 & 0 & 0 & 0 & 0 & 100 & 100 & 100 \\
\hline 9. Vegetable oil \& fats & 0 & 0 & 0 & 0 & 0 & 0 & 0 & 100 & 100 & 100 \\
\hline 10. Milk products & 0 & 0 & 0 & 0 & 0 & 0 & 0 & 100 & 100 & 100 \\
\hline 11. Other food products & 0 & 0 & 0 & 0 & 0 & 0 & 0 & 100 & 100 & 100 \\
\hline 12. Beverages \& tobacco & 0 & 0 & 0 & 0 & 0 & 0 & 0 & 100 & 100 & 100 \\
\hline 13. Mining & 35 & 50 & 0 & 35 & 50 & 35 & 50 & 100 & 100 & 100 \\
\hline 14. Textiles & 35 & 25 & 0 & 35 & 25 & 35 & 25 & 100 & 100 & 100 \\
\hline 15. Weaving apparel \& leather & 35 & 50 & 0 & 35 & 50 & 35 & 50 & 100 & 100 & 100 \\
\hline 16. Wood \& wood products & 35 & 50 & 0 & 35 & 50 & 35 & 50 & 100 & 100 & 100 \\
\hline 17. Paper \& paper products & 35 & 50 & 0 & 35 & 50 & 35 & 50 & 100 & 100 & 100 \\
\hline 18. Chemical, rubber \& plastic & 35 & 50 & 0 & 35 & 50 & 35 & 50 & 100 & 100 & 100 \\
\hline 19. Nonmetallic mineral products & 35 & 50 & 0 & 35 & 50 & 35 & 50 & 100 & 100 & 100 \\
\hline 20. Basic metal products & 50 & 50 & 0 & 50 & 50 & 50 & 50 & 100 & 100 & 100 \\
\hline 21. Fabricated metal products & 35 & 50 & 0 & 35 & 50 & 35 & 50 & 100 & 100 & 100 \\
\hline 22. Other manufactures & 35 & 50 & 0 & 35 & 50 & 35 & 50 & 100 & 100 & 100 \\
\hline 23. Construction & 0 & 0 & 0 & 0 & 0 & 0 & 0 & 100 & 100 & 100 \\
\hline 24. Services & 0 & 0 & 0 & 0 & 0 & 0 & 0 & 100 & 100 & 100 \\
\hline
\end{tabular}

Note: The base period ad valorem tariff rates are changed as exogenous shocks by the percentages shown in the table under different trade liberalisation scenarios. The percentages were designed in accord with the ILFFTA details on tariff reductions.

first two columns of Table 6. The changes in tariff rates for scenario two (IndoLanka-Rest of South-Asia partial free trade) are shown in columns 4 to 7 of the table. All three regions reduce tariffs on reciprocal basis. Finally, the scenario three (Indo-Lanka-Rest of South Asia full free trade) involved complete removal of all ad valorem tariff rates on South Asia-sourced imports of each of the three regions bilaterally. In all three scenarios, import duties between rest of the regions and regions in South Asia are maintained.

The tariff simulations were conducted in the long-run framework with capital mobility across each region. This implies that the changes in rates of return are also equalised across regions. Investment takes place in each economy during the 
period of tariff reductions making sure that sum of the regional investment matches with the changes in global savings. In addition we assume that aggregate employment of labour and land are fixed in each region.

\section{Results of the GTAP Simulations}

This section reports the impact of the ILFTA and its extension to the rest of South Asia on important macroeconomic variables, sectoral outputs, and export performance. In order to isolate the outcome of the ILFTA from other trade liberaliasation options considered in the paper, results are presented under each of the three scenarios.

\section{A. Indo-Lanka Partial Free Trade Scenario}

The first panel of Table 7 shows the macroeconomic and welfare effects of the tariff reductions as stipulated in the ILFTA. We find that the free trade agreement has a much bigger impact on the Sri Lankan economy than on the Indian economy. Sri Lanka's real GDP increases by 0.24 per cent whereas there is only a negligible change in India's real GDP (0.02 per cent). Similarly, the trade results reported in Table 7 indicate a considerable expansion of export and import volumes of Sri Lanka. As imports grow faster than exports, a negative trade balance (US\$ 13.1 millions) becomes inevitable. The trade expansion for India is trivial with a small positive trade balance. Perhaps Sri Lanka's more openness could be an explanatory factor for the noticeable performance at the trade front in comparison to its RTA partner.

Other interesting aspects of the macroeconomic results relate to the terms of trade effect and real returns to unskilled labour. It appears that the ILFTA may lead to an adverse terms of trade for Sri Lanka. India is projected to gain in its terms of trade though it is very marginal. The terms of trade decline for Sri Lanka may be due to its relative smallness of export trade with India and the similarity of the products both nations export. In a competitive market environment with open freer trade, Sri Lanka is perhaps experiencing a competitive disadvantage. The unskilled labour force in Sri Lanka may experience a considerable improvement in their real incomes as a result of trade liberalisation under the agreement. This is a desirable outcome and is welcomed by policy makers as many of those workers are employed in highly unskilled labour intensive export oriented sectors such as textiles, and weaving apparel and leather. The welfare gains as projected by the equivalent variation is positive for both trading partners and Sri Lanka is placed in a better position when such gains are 
Table 7. Macroeconomic and Trade Performance Results of Different Liberalisation Scenarios

\begin{tabular}{|c|c|c|c|c|c|c|c|c|}
\hline & $\begin{array}{l}\text { Real } \\
\text { GDP }\end{array}$ & $\begin{array}{l}\text { Export } \\
\text { Volume }\end{array}$ & $\begin{array}{l}\text { Import } \\
\text { Volume }\end{array}$ & $\begin{array}{l}\text { Terms } \\
\text { f Trade }\end{array}$ & $\begin{array}{c}\text { Balance } \\
\text { of Trade } \\
\text { (US \$ } \\
\text { million) }\end{array}$ & $\begin{array}{l}\text { Equiva- } \\
\text { lent Vari- } \\
\text { ation (US I } \\
\$ \text { million) }\end{array}$ & $\begin{array}{l}\text { GDP } \\
\text { Deflato }\end{array}$ & $\begin{array}{c}\text { Real } \\
\text { Return to } \\
\text { Unskilled } \\
\text { Labour }\end{array}$ \\
\hline \multicolumn{9}{|l|}{$\begin{array}{l}\text { Indo-Lanka Partial Free Trade } \\
\text { Scenario: }\end{array}$} \\
\hline Sri Lanka (LKA) & 0.24 & 0.49 & 0.64 & -0.03 & -13.18 & 21.77 & 0.07 & 0.37 \\
\hline India (IND) & 0.02 & 0.08 & 0.07 & 0.02 & 7.32 & 65.68 & 0.02 & 0.02 \\
\hline Rest of South Asia (RSA) & 0.00 & 0.00 & 0.00 & 0.00 & 0.14 & -1.07 & 0.00 & 0.00 \\
\hline North America (NAM) & 0.00 & 0.00 & 0.00 & 0.00 & 1.65 & -5.05 & 0.00 & 0.00 \\
\hline Japan (JPN) & 0.00 & 0.00 & 0.00 & 0.00 & -2.08 & -12.07 & 0.00 & 0.00 \\
\hline Australia-New Zealand (ANZ) & 0.00 & 0.00 & 0.00 & 0.00 & 0.17 & -0.13 & 0.00 & 0.00 \\
\hline China $(\mathrm{CHN})$ & 0.00 & 0.00 & 0.00 & 0.00 & 0.32 & -4.02 & 0.00 & 0.00 \\
\hline Rest of East Asia (REA) & 0.00 & 0.00 & 0.00 & 0.00 & 1.21 & -8.25 & 0.00 & 0.00 \\
\hline European Union (EU) & 0.00 & 0.00 & 0.00 & 0.00 & 1.80 & -5.42 & 0.00 & 0.00 \\
\hline Rest of World (ROW) & 0.00 & 0.00 & 0.00 & 0.00 & 2.64 & -0.91 & 0.00 & 0.00 \\
\hline \multicolumn{9}{|l|}{$\begin{array}{l}\text { Indo-Lanka-Rest of South Asia } \\
\text { Partial Free Trade Scenario: }\end{array}$} \\
\hline Sri Lanka (LKA) & 0.46 & 1.05 & 1.14 & 0.01 & -14.98 & -46.40 & 0.23 & 0.61 \\
\hline India (IND) & 0.46 & 1.59 & 1.49 & 0.39 & 195.61 & 1525.64 & 0.55 & 0.42 \\
\hline Rest of South Asia (RSA) & 0.13 & 2.13 & 2.20 & -0.60 & -207.39 & -43.59 & -0.46 & 0.62 \\
\hline North America (NAM) & 0.00 & 0.00 & 0.00 & 0.00 & 19.18 & -64.13 & 0.00 & 0.00 \\
\hline Japan (JPN) & 0.00 & -0.01 & -0.01 & 0.00 & -43.90 & -180.82 & 0.00 & -0.01 \\
\hline Australia-New Zealand (ANZ) & 0.00 & 0.00 & 0.00 & 0.00 & 2.78 & 3.37 & 0.00 & 0.00 \\
\hline China $(\mathrm{CHN})$ & -0.01 & -0.01 & -0.02 & 0.00 & 7.42 & -87.79 & -0.01 & -0.01 \\
\hline Rest of East Asia (REA) & -0.01 & -0.01 & -0.02 & 0.00 & 15.88 & -121.93 & 0.00 & -0.01 \\
\hline European Union (EU) & 0.00 & 0.00 & 0.00 & 0.00 & 5.27 & -86.11 & 0.00 & 0.00 \\
\hline Rest of World (ROW) & 0.00 & 0.00 & -0.01 & 0.00 & 20.14 & -64.87 & 0.00 & 0.00 \\
\hline \multirow{2}{*}{\multicolumn{9}{|c|}{$\begin{array}{l}\text { Indo-Lanka-Rest of South Asia } \\
\text { Full Free Trade Scenario: }\end{array}$}} \\
\hline & & & & & & & & \\
\hline Sri Lanka (LKA) & 3.07 & 7.10 & 7.72 & 1.17 & -54.79 & 365.29 & 3.00 & 3.49 \\
\hline India (IND) & 3.23 & 13.28 & 12.57 & 2.86 & 1609.33 & 10877.01 & 3.98 & 3.12 \\
\hline Rest of South Asia (RSA) & -3.14 & 36.90 & 25.76 & -5.80 & -1134.63 & -4331.30 & -5.90 & 3.46 \\
\hline North America (NAM) & -0.01 & 0.00 & 0.00 & 0.00 & -12.95 & -515.60 & -0.01 & -0.01 \\
\hline Japan (JPN) & -0.02 & -0.08 & -0.04 & -0.02 & -301.39 & -940.54 & -0.02 & -0.02 \\
\hline Australia-New Zealand (ANZ) & 0.00 & 0.00 & -0.01 & 0.00 & 0.70 & -1.03 & -0.01 & 0.00 \\
\hline China (CHN) & -0.07 & -0.11 & -0.15 & -0.04 & -5.25 & -663.04 & -0.07 & -0.07 \\
\hline Rest of East Asia (REA) & -0.06 & -0.09 & -0.12 & -0.03 & 47.71 & -934.31 & -0.04 & -0.05 \\
\hline European Union (EU) & -0.01 & -0.02 & -0.01 & -0.01 & -159.05 & -416.55 & -0.01 & -0.01 \\
\hline Rest of World (ROW) & -0.01 & -0.03 & -0.04 & -0.01 & 10.23 & -396.43 & -0.01 & -0.01 \\
\hline
\end{tabular}

Source: Author's simulations of GTAP.

Note: All projections are percentage deviations from the base except the balance of trade and the equivalent variation. Changes in these two variables are measured in US\$ millions. 
Table 8. Sectoral Output Changes Under Different Trade Liberalisation Scenarios

\begin{tabular}{|c|c|c|c|c|c|c|c|c|c|}
\hline \multirow[t]{2}{*}{ Sector } & \multicolumn{3}{|c|}{$\begin{array}{c}\text { Indo-Lanka Partial Free } \\
\text { Trade Scenario }\end{array}$} & \multicolumn{3}{|c|}{$\begin{array}{c}\text { Indo-Lanka-Rest of } \\
\text { South Asia Partial Free } \\
\text { Trade Scenario }\end{array}$} & \multicolumn{3}{|c|}{$\begin{array}{c}\text { Indo-Lanka-Rest of South } \\
\text { Asia Full Free Trade Sce- } \\
\text { nario }\end{array}$} \\
\hline & LKA & IND & RAS & LKA & IND & RSA & LKA & IND & RSA \\
\hline Rice & 0.07 & 0.00 & 0.00 & 0.15 & 0.00 & 0.04 & 1.10 & -0.34 & 0.78 \\
\hline Wheat & -0.11 & 0.00 & 0.00 & -0.25 & 0.10 & 0.00 & -4.71 & 0.64 & -0.32 \\
\hline Other cereal grains & 0.02 & 0.00 & 0.00 & 0.03 & 0.11 & -0.03 & -0.31 & 0.74 & -1.54 \\
\hline Vegetables \& fruits & 0.06 & 0.00 & 0.00 & 0.14 & 0.06 & 0.07 & 3.19 & 0.83 & -0.65 \\
\hline Sugar & -0.18 & 0.01 & 0.00 & -0.25 & 0.18 & 0.03 & 27.17 & 1.22 & -1.07 \\
\hline Plant-based fibers & -0.20 & 0.01 & 0.00 & -0.43 & 0.12 & 0.08 & -2.24 & 0.49 & 3.07 \\
\hline Other crops & -0.29 & -0.01 & 0.01 & -0.58 & -0.23 & 0.12 & -3.54 & 1.93 & -5.25 \\
\hline Meat products & 0.44 & 0.01 & 0.00 & 0.62 & 0.13 & 0.07 & 2.77 & 0.95 & -0.99 \\
\hline Vegetable oil \& fats & -0.04 & 0.00 & 0.00 & -0.18 & 0.00 & 0.08 & 55.28 & -0.45 & 1.77 \\
\hline Milk products & 0.13 & 0.01 & 0.00 & 0.21 & 0.19 & 0.08 & 1.83 & 1.33 & -1.16 \\
\hline Other food products & 0.07 & -0.01 & 0.00 & 0.16 & -0.21 & -0.07 & 0.23 & 0.31 & -1.32 \\
\hline Beverages \& tobacco & 0.18 & 0.01 & 0.00 & 0.36 & 0.29 & -0.03 & 24.77 & -8.40 & 8.22 \\
\hline Mining & 0.15 & 0.01 & 0.00 & 0.24 & 0.46 & -0.73 & 1.21 & 2.07 & -4.57 \\
\hline Textiles & 0.08 & 0.04 & 0.00 & 0.82 & 0.33 & 0.05 & 2.64 & 6.09 & 0.51 \\
\hline Weaving apparel \& leather & 0.81 & -0.07 & 0.00 & 1.58 & -1.71 & 2.06 & 5.10 & -9.30 & 32.84 \\
\hline Wood \& wood products & 0.26 & 0.03 & 0.00 & 0.88 & 0.65 & 0.22 & 9.24 & 4.64 & -3.88 \\
\hline Paper \& paper products & 0.90 & 0.07 & 0.00 & 1.26 & 0.86 & -0.44 & 6.66 & 5.36 & -4.03 \\
\hline Chemical, rubber \& plastic & 0.75 & 0.02 & 0.00 & 1.33 & 0.71 & 0.09 & 8.72 & 3.62 & 1.43 \\
\hline Nonmetallic mineral products & 0.14 & 0.11 & 0.00 & 0.74 & 2.22 & -4.77 & 3.17 & 11.96 & -27.14 \\
\hline Basic metal products & 0.57 & 0.09 & 0.00 & 8.31 & 1.40 & -1.68 & 33.55 & 8.62 & -11.23 \\
\hline Fabricated metal products & 2.92 & 0.07 & 0.00 & 4.53 & 2.12 & -1.13 & 42.42 & 11.45 & -5.01 \\
\hline Other manufactures & 0.34 & 0.02 & 0.00 & 1.12 & 0.49 & 0.45 & 14.11 & 3.10 & 1.17 \\
\hline Construction & 0.70 & 0.02 & 0.00 & 0.98 & 0.50 & 1.20 & 5.33 & 3.37 & 4.28 \\
\hline Services & 0.08 & 0.02 & 0.00 & 0.19 & 0.42 & 0.03 & 1.52 & 2.97 & -2.64 \\
\hline
\end{tabular}

Source: Author's simulation of GTAP.

Note: The percentage changes in the table are the output changes in each sector in different economies in response to alternative tariff reduction (elimination) scenarios adopted.

considered relative to the real GDP.

In general the ILFRA seems to have no discernible effect on rest of the world. Japan is likely to be the only country which may experience some impact of the free trade agreement between India and Sri Lanka. This is explained by the fact that Japan is relatively an important trading partner for both countries. As expected in theory, there seems to be a minor negative welfare effect on rest of the world.

The sectoral output changes appear in Table 8 . The industrial structure of the Indian economy is largely non-responsive to trade liberalisation under the ILFTA. While nonmetalic mineral product sector experiences 0.1 per cent output gain, all other sectors show almost zero percent change in their outputs. The converse is true for Sri Lanka. Many sectors respond positively to the bilateral tariff cuts. As agricultural sectors face no reduction in tariffs under the arrangements of 
Table 9. Changes in Export Volumes Under Different Trade Liberalization Scenarios

\begin{tabular}{|c|c|c|c|c|c|c|c|c|c|}
\hline \multirow[t]{2}{*}{ Sector } & \multicolumn{3}{|c|}{$\begin{array}{l}\text { Indo-Lanka Partial } \\
\text { Free Trade Scenario }\end{array}$} & \multicolumn{3}{|c|}{$\begin{array}{c}\text { Indo-Lanka-Rest of } \\
\text { South Asia Partial Free } \\
\text { Trade Scenario }\end{array}$} & \multicolumn{3}{|c|}{$\begin{array}{c}\text { Indo-Lanka-Rest of } \\
\text { South Asia Full Free } \\
\text { Trade Scenario }\end{array}$} \\
\hline & $\begin{array}{l}\text { LKA } \\
\end{array}$ & IND & RAS & LKA & IND & RSA & LKA & IND & RSA \\
\hline Rice & -0.44 & -0.09 & 0.01 & -0.61 & -2.00 & 0.33 & -13.87 & -19.96 & 13.36 \\
\hline 2. Wheat & -0.51 & -0.13 & 0.00 & -1.11 & -2.86 & 0.17 & -15.64 & -21.39 & 7.76 \\
\hline 3. Other cereal grains & -0.63 & -0.11 & 0.06 & -1.52 & -2.89 & 1.35 & -21.61 & -22.38 & 17.54 \\
\hline 4. Vegetables \& fruits & -0.92 & -0.12 & 0.02 & -1.79 & -2.80 & 0.42 & 64.33 & 9.88 & 255.97 \\
\hline 5. Sugar & -0.52 & -0.07 & 0.01 & -0.53 & -2.34 & 0.23 & 270.77 & 17.25 & 19.16 \\
\hline 6. Plant-basec & -0.44 & -0.13 & 0.01 & -0.92 & -2.88 & 0.08 & -10.13 & -3.48 & 31.19 \\
\hline 7. Otl & & & 01 & -0.84 & -2.42 & 0.14 & -7.15 & 12.03 & 47.63 \\
\hline 8. Mea & - & 4 & 0.00 & -2.32 & -3.00 & -0.28 & -10.04 & -20.22 & 37.25 \\
\hline 9. Veget & -0.43 & -0.10 & 0.02 & -1.17 & -2.14 & 0.77 & 170.09 & -14.53 & 223.85 \\
\hline 10. $\mathrm{N}$ & -0.20 & -0.14 & 0.02 & -0.59 & -2.92 & 0.18 & 3.93 & -20.27 & 84.00 \\
\hline 11. Oth & 3 & -0.06 & 0.00 & -0.70 & -1.28 & -0.10 & -5.74 & -0.40 & 18.31 \\
\hline 12. $\mathrm{Bc}$ & -0.25 & -0.14 & 0.02 & -0.75 & -3.10 & 1.26 & 637.54 & 778.54 & 518.44 \\
\hline 13. M & 0.11 & -0.03 & 0.00 & 0.06 & 0.48 & 5.16 & -0.82 & -0.22 & 29.51 \\
\hline 14. $\mathrm{Te}$ & 0.32 & 0.21 & 0.00 & 3.24 & 1.42 & 1.55 & 9.80 & 36.64 & 24.21 \\
\hline 15. W & 0.84 & -0.16 & -0.01 & 1.64 & -3.50 & 2.77 & 5.09 & -18.32 & 49.27 \\
\hline 16. Wood \& & -0.65 & 0.16 & 0.01 & 2.19 & 5.43 & 27.34 & 41.62 & 33.06 & 116.17 \\
\hline 17. Paper \& paper products & 12.80 & 1.87 & -0.02 & 15.46 & 13.45 & 2.36 & 62.74 & 80.29 & 16.81 \\
\hline 18. Chemical, rubber \& plas & 1.76 & 0.11 & -0.03 & 2.89 & 4.43 & 19.40 & 17.28 & 18.94 & 99.29 \\
\hline 19. Nonme & 0.65 & 0.86 & -0.05 & 3.47 & 17.70 & 3.07 & 4.36 & 90.26 & 27.61 \\
\hline 20. Basic $n$ & 11.64 & 0.60 & -0.05 & 70.84 & 6.81 & 19.46 & 248.49 & 48.79 & 140.95 \\
\hline 21. Fabricated metal products & 6.51 & 0.68 & -0.01 & 9.96 & 18.28 & 6.49 & 94.18 & 102.47 & 59.02 \\
\hline 22. Other manufactures & 0.34 & -0.02 & 0.00 & 1.12 & -1.37 & 3.24 & 14.20 & -8.18 & 29.35 \\
\hline 23. Const & 0.12 & -0.07 & 0.00 & -0.53 & -1.56 & 2.47 & -7.52 & -10.55 & 21.55 \\
\hline 24. Services & -0.69 & -0.08 & 0.00 & -1.37 & -1.88 & 0.48 & -10.00 & -12.53 & 9.44 \\
\hline
\end{tabular}

Source: Author's simulation of GTAP.

Note: The numbers in the table are percentage deviations from the base period indicating how exports (volumes) of each economy will change in response to the different trade liberalisation scenarios.

"negative list", tariff reforms tend to reduce most of the sectoral outputs. The significant winners of the INLFTA on the Sri Lankan side are manufacturing sectors that are highly export oriented and that are heavily dependent on imported inputs. The fabricated metal products sector shows 2.9 per cent improvements in output and is a good example for the latter category. The model projects an appreciable performance for most of the manufacturing sectors which have export market in India. The changes in export volumes reported in Table 9 are consistent with the output responses which are projected by the model.

\section{B. Indo-Lanka-Rest of South Asia Partial Free Trade Scenario}

In this second trade liberalisation scenario, we consider that Sri Lanka and India offer same reciprocal tariff reduction arrangements to RSA. It is then similar to 
establishing partial free trade area within South Asia. As shown by results in panel two of Table 7, such trilateral liberalisation approach tends to have much bigger impact on real GDP of both Sri Lanka and India than of RSA. Export and import volumes of all three regions increase while RSA being the winner in trade performance. However, its terms of trade decline, as trade is liberlised in the region leaving a small gain in its overall GDP.

Consistent with poor terms of trade, Sri Lanka and RSA are likely to experience trade deficits in the event of partial trade liberalisation being adopted in South Asia. Interestingly, India turns out to be a considerable gainer from this trilateral tariff cut compared to the Indo-Lanka partial free trade scenario. This is clearly evident from the improvement in welfare as measured by the equivalent variation. Sri Lanka and RSA are projected to lose their overall welfare despite improvements in their GDP. However, the unskilled labour in South Asia tends to improve their real income in much similar fashion across regions.

As in the case of bilateral tariff cuts between India and Sri Lanka, the rest of the world regions show no change in their real GDP except China and REA which show negligible declines in GDP. Australia-New Zealand region is likely to have minor welfare gain whereas all other regions are projected to have negative equivalent variations in response to the formation of the South Asian partial free trade area.

Turning to the sectoral results in Table 8, it is noticed that India is beginning to gather momentum from the trilateral tariff cuts as shown by the improvements in output performance of almost all the sectors. Sri Lanka consolidates its sectoral output changes in mining, manufacturing and service sectors at the expense of the country's agricultural sectors. The latter group appears to be much more unfavourably affected. RSAs response in terms of sectoral outputs is somewhat mixed and a third of its sectors are showing reductions in their outputs. The export projections reported in Table 9 under this scenario indicate that Sri Lanka and India improve their export volumes considerably and RSA also keeps up with the regional trend. Agricultural exports of Sri Lanka and India are affected badly whereas RSAs exports in that group of commodities experience a reasonable expansion.

\section{Indo-Lanka-Rest of South Asia Full Free Trade Scenario}

In this trade scenario, all bilateral tariffs are removed among member countries, while leaving tariff rates unchanged with nonmember countries. The trade policy thus discriminates against non-South Asian countries but at the same time creates improved market access for member countries within the region. As can be seen 
from Table 7 (panel three), the policy of full free trade in South Asia is by far the best option for India and Sri Lanka. Unfortunately, it is the worst for RSA as their real GDP declines (by 3.1 per cent) dramatically by entering into full free trade.

This contraction in real GDP for RSA is mainly due to the adverse impact on the terms of trade that the region is projected to experience. The RSA's volume of exports grows at a faster rate than that of India and Sri Lanka and its increase in import volume is well below that of exports. However, the declining terms of trade means reduced purchasing power for RSA's exports, which has undoubtedly created a considerable trade deficit for the region. Ultimately this trade deficit dictates the impact on real GDP in the region. Despite declining GDP, unskilled workers in RSA experience an increase in wage rate. This wage rise is due to the huge expansion in the output of Weaving, apparel \& leather sector (by 32.8 per cent) where majority of the unskilled workers are employed. As Table 8 shows, this sector expands at the expense of many other sectors and has a tendency to increase the demand for unskilled labour in the economy. With the deflationary effects of liberalisation in general, the real returns to unskilled labour rise.

As in previous two trade policy scenarios, both Sri Lanka and RSA experience much higher trade deficits. The results also indicate that the free trade area favours the largest nation, namely India, and it is projected to have substantial welfare gains as measured by the equivalent variation. Consistent with the decline in real GDP, RSA is likey to be worse off in terms of welfare though unskilled labour force seemed to have achieved higher real incomes comparable to other RTA partners.

The formation of free trade area in South Asia may have trivial negative effect on nonmember countries (i.e., rest of the world regions). As would be expected, Asian neighbours (Japan, China, REA) seem to experience a relatively higher impact. However, the magnitudes are not alarming relative to the size of GDP of these countries and regions so that it is safe to assume that the free trade in South Asia may not be a severe threat to the world economy.

Judging from the sectoral results of Table 8 and the export projections in Table 9 , India emerges to be a clear winner of free trade in the region. The entire removal of trade tariffs favours all sectors except weaving apparel and leather, beverages and tobacco, and rice sectors. Interestingly, for Sri Lanka, the fear of agriculturists for free trade in South Asia is lessened to some extent as many sectors now experience considerable output gains. The economy in general is blessed by the improved market access in the region as shown by a considerable increase in sectoral performance. The free trade tends to fair poorly RSA as majority of its 
sectors are projected to have their outputs declined.

\section{Conclusion}

In this paper we have used the GTAP model to quantify the impact of the free trade agreement between India and Sri Lanka. We also illustrate the implications of the extension of such agreement to include all SARRC countries. A departure from partial free trade as stipulated in the agreement to full free trade in South Asia is also examined in order to measure the impact on the regional economic performance.

Several important conclusions could be drawn from the analysis of different free trade scenarios for South Asia. Based on simulation results of the Indo-Lanka partial free trade scenario, Sri Lanka seems to benefit relatively more than India from the ILFTA as shown by both GDP and welfare projections. The trade agreement may enhance more imports from India to Sri Lanka at a much cheaper price than before but the growth in exports is likely to be insufficient to pay for the increase in imports. Thus an inevitable outcome for Sri Lanka is an increase in the trade deficit which may perhaps result in a smaller growth in real GDP than expected. The ILFTA seems to have relatively minor impact on India. Its performance does not change much in GDP terms in response to liberalised trade with Sri Lanka due to the relatively small trade that takes place between the two countries. Surely, the reduction in duties by the Sri Lankan economy opens up a new market for Indian exporters and hence a positive trade balance is likely against Sri Lanka. As would be expected, the free trade agreement has no significant influence on RSA as well as on rest of the world.

The extension of the ILFTA to all SAARC countries could be an interesting trade policy scenario for South Asia. Our results indicate that Sri Lanka would benefit from such regional trading arrangements by almost doubling its GDP performance experienced from the ILFTA. India being the largest economy in the region could improve its benefits from liberalisation in trade within the region and it has the potential to gain more than other members. Its trade balance will improve while other members (i.e., Sri Lanka and RSA) experience substantial deficits. The deterioration of the terms of trade for RSA is somewhat disturbing news resulting a slower GDP growth for that group of countries in South Asia.

Our findings from the full free trade scenario in South Asia suggest that Sri Lanka and India will be clear winners while RSA becomes a looser in terms of GDP 
growth. The latter group appears to be severely affected by the adverse terms of trade with the elimination of bilatteral tariffs. India being the largest economy in the region may enjoy the highest benefits from full free trade in South Asia. The improved market access in the region is in favor of all South Asian nations and our results clearly show that regional trade will expand considerably. The unskilled labour force in the region will experience a real income growth. The results provide some empirical evidence that nonmembers welfare could be reduced with the formation of the South Asian free trade area though the extent of change in welfare is trivial relative to the size of the nonmembers.

The policy implication from the results is that the bilateral trade liberalisation under the ILFTA is not as bad as some segments of industrialists argue in Sri Lanka. It is possible to remove tariff barriers without severely affecting the economic performance of the country. There seems to be considerable gains to Sri Lanka from the agreement in the long run. However, these gains are realised at the expense of an increased trade deficit. The extension of the agreement to all SARRC nations under SAFTA is likely to benefit the region as a whole by increased trade within South Asia. The SAARC nations should work hard to implement the SAFTA as soon as possible as it appears to be potentially more beneficial than bilateral trade liberalisation for real GDP growth in the region. Full free trade in South Asia under SAFTA may perhaps disadvantage smaller countries in the region and the SAARC must be prepared to offer necessary assistance for such nations to ensure their full participation in the agreement. Tension may arise between agriculture and manufacturing under free trade in South Asia, as the latter is likely to expand faster with the removal of trade barriers. Such structural imbalance cannot be overlooked since a considerable proportion of the labour force is still engaged in agriculture in South Asia.

\section{Acknowledgements}

The author acknowledges the helpful comments and suggestions from the anonymous referee. The paper also benefited from comments of participants of the Biennial Conference of Hong Kong Economic Association on the Asian Pacific Economies in the New Millenium, December 14-16, 2000, Hong Kong. The University of New England provided financial support for this research. 


\section{References}

Bhagwati, J. and Panagariya, A. (1996). The Economics of Preferential Trade Agreements, Washington D.C., AEI Press.

Central Bank of Sri Lanka (1999, pp.138-39). Annual Report: 1998, Colombo, Sri Lanka. Krueger, A. O. (1999). "Are Preferential Trading Arragements Trade-Liberalizing or Protectionist?," Journal of Economic Perspectives, 13: 105-124.

Dixon, P.B., Parmenter, B.R., Sutton, J. and Vincent, D.P. (1982). ORANI: Multisectoral Model of the Australian Economy, Amsterdam, North-Holland.

Hertel, T.W. (1996). Global Trade Analysis: Modelling and Applications, , New York and Cambridge, Cambridge University Press.

International Monetary Fund, Direction of Trade Statistics Yearbook, various issues.

McDougall, R.A., Elbehri, A. Truong, T.P. (1998). Global Trade, Assistance, and Protection, Centre for Global Trade Analysis, Purdue University.

Mukherji, I.N. (1998). "The South Asian Preferential Trading Arrangement: Identifying Products in Indias Regional Trade," Asia-Pacific Development Journal, 5: 37-70.

Panagariya, A. (1996), "The Free Frade Areas of Americas : Good for Latin America?", The World Economy, 19: 485-516.

Panagariya, A. (1998), “The Regionalism Debate : An Overview,” Center for International Economics, Department of Economics, University of Maryland at Collegepark, Working paper NO.40

Panagariya, A. (1999), "The Trade Policy in South Asia : Recent Liberalization and Future Agenda", The World Economy, 22: 353-377

Srinivasan, T. N. (1994), "Regional Trading Arrangement and Beyond : Exploring some Options for South Asia : Theory, Empirics, and Policy”, Report No. IDP-142, World Bank, Washington D.C.

Srinivasan, T.N. (1998), Developing Countries and the Multinational Trading System : From GATT to the Uruguay Round and the Future, Dehli: Oxford University Press.

Siriwardana, M. (2000). "Looking Beyond SAARC: Some Trade Liberalisation Options for Sri Lanka," Asian Studies Review, 25: 453-477. 
Appendix A1. Regional and Commodity Aggregation

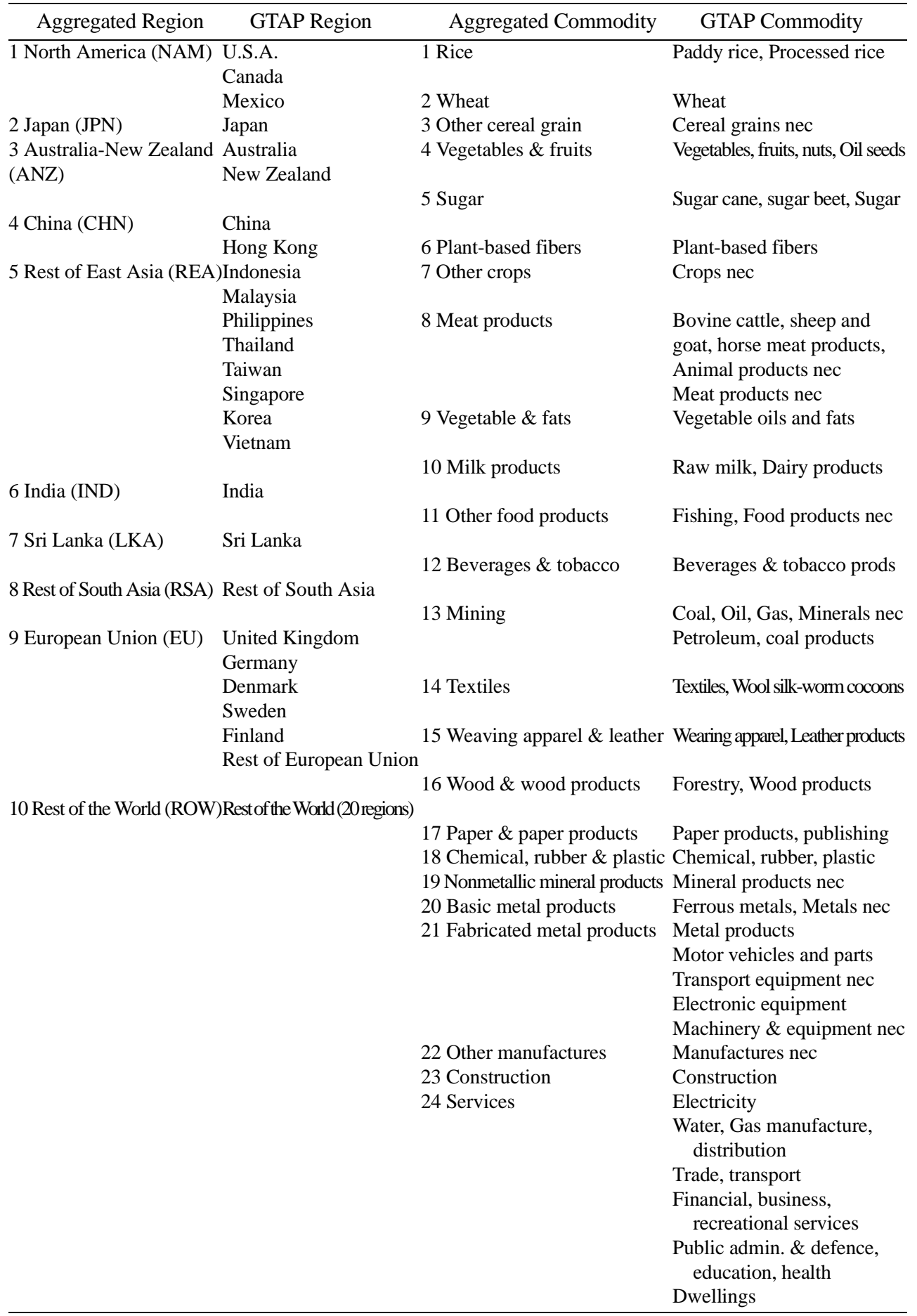

Source: McDougall et al., 1998. 